clinical effectiveness. At a time when the Department of Health is considering future arrangements for both accreditation and clinical audit the scope for bringing them closer together merits serious attention.

RAY ROBINSON Professor of health policy

Institute for Health Policy Studies,

University of Southampton,

Southampton SO17 1BJ
1 Drummond M, Maynard A, eds. Purchasing and providing cost-effective health care. Edinburgh: Churchill Livingstone, 1993.

2 Ovretveit J. Purchasing for health. Buckingham: Open University Press, 1995.

3 Scrivens E. Accreditation: protecting the professional or the consumer? Buckingham: Open University Press, (in press).

4 Brooks T. King's Fund organisational audit. King's Fund News, 1994;17(3):1-3.

5 King's Fund Organisational Audit. Hospital accreditation programme: organisational standards and criteria. London: King's Fund, 1994.

Shaw C, Collins C. Health service accreditation: report of a pilot programme for communiry hospitals. BMf̊ 1995;310:781-4.

7 Shaw C, Hurst M, Stone S. Towards good practice in small hospitals. Birmingham: National Association of Health Authorities, 1988.

8 Packwood T, Keen J, Buxton M. Hospitals in transition. Buckingham: Open University Press, 1991.

\title{
Mutual trust?
}

\section{Trusts should read the small print of the new NHS Mutual Fund}

As the vesting date of the new NHS Mutual Fund approaches, trusts are thronging to sign up for the scheme, which is designed to "protect ... against the adverse effects of large clinical negligence claims." Currently, trusts deal with this risk in two ways: by allocating amounts from their budgets to meet small claims and by borrowing from the NHS to spread the cost of large claims over several years. Trusts fear large settlements because having to pass them on to purchasers through prices could make them uncompetitive. But this fear may be exaggerated, and trusts need accurate information on which to base their decision whether to continue with the current approach or to subscribe to the new scheme. After all, every pound paid into the fund is one less pound for patients' care.

As recent experiences with personal pensions and endowment mortgages should remind us, proposals for insurance need to be read with great care and hard questions need to be asked. The financial directors of trusts are supposed to be skilled purchasers of services. The particular difficulty with the proposed scheme, however, is that its full costs will not be known until it is in its maturity, some 10 years hence. This is because it is being brought in on the basis of "pay as you go," which means that claims in each year are met from the payments in the same year, regardless of when, after trusts joined the scheme, the events occurred. Consequently, a judgment about the scheme's value for money must be based on trusts' anticipated future liabilities for clinical negligence. Here the quality of information made available to trusts by the scheme's managers becomes critical.

The arithmetic is simple. Ultimately, the contributions needed to cover liabilities will be calculated by reference to three statistics: the number of claims received, the probability that payment will be made for these claims, and the average cost per claim. In an illustrative calculation prepared for the induction seminars the scheme's managers assume that there will be about 150 claims per 1000 (whole time equivalent) doctors at an average cost of $£ 50000$ per claim, whether claims are settled out of court or go to trial.

These figures are conservative but not unrealistic. Our data from 1990-1 suggest 105 claims per 1000 doctors at an average cost of just over $£ 27000 .^{2}$ Recent figures from regional health authorities suggest that the frequency and severity of claims may well have grown since then. ${ }^{3}$ What is astonishing, however, is that, when projecting trusts' future liabilities from current claims, the fund's managers assume that each claim will result in a payment. We and others estimate that only one quarter to one third of claims end with a payment to the claimant..$^{4-6}$ The result is that the scheme's managers are exaggerating the predicted future liabilities of trusts by a factor of at least three. By extension, it seems that the initial contributions will be unnecessarily high. Clearly, if the fund built up a surplus as a result this would ultimately find its way back to members and into the NHS. But this does not seem an efficient approach to the planning of patients' care over time. Unnecessarily high initial contributions to the scheme will mean that prices to purchasers will be inflated so that current patients' care will suffer.

Before opting into the new scheme trusts should be clear about the true costs and benefits. Trusts may still decide in favour of this approach for understandable and justifiable reasons, not least its potential contribution to the development of effective risk management. An alternative, however, would be to continue to meet small claims out of current revenue and to use the NHS loan scheme or phased payments to smooth any large fluctuations. For some trusts this might make more sense. Their judgment ought not to be clouded by misleading projections of future liabilities. They should bear in mind that, though litigation may be increasing, patients do not always win.

PAUL FENN

Norwich Union professor of insurance studies

School of Management and Finance,

University of Nottingham,

Nottingham NG7 2RD

ROBERT DINGWALL

School of Social Studies

Professor of social studies

1 Clinical negligence scheme for trusts. Leeds: NHS Executive, Touche Ross, Medical Protection Society, Willis Corroon, 1995

2 Fenn P, Hermans D, Dingwall R. Estimating the costs of compensating victims of medical negligence. $B M \mathcal{F}$ 1994;309:389-91.

Brindle D. Errors cost NHS $f 125 \mathrm{~m}$ a year. Guardian 19958 Mar:5.

4 Bowles R, Jones P. A health authority's experience. New Law foumal 1989:139:119-23.

4 Bowles R, Jones P. A health authority's experience. New Law fournal 1989:139:119-23. In: Dingwall R, Fenn P, eds. Quality and regulation in health care. London: Routledge, 1992:11-25. 6 Hawkins C, Paterson I. Medicolegal audit in the West Midlands: analysis of 100 cases. BMF 1987;295:1533-6. 